\title{
ВЫБОР БУДУЩЕЙ ПРОФЕССИИ - ЗАЛОГ УСПЕШНОЙ СОЦИАЛЬНОЙ АДАПТАЦИИ
}

\section{CHOOSING A FUTURE PROFESSION IS THE KEY TO SUCCESSFUL SOCIAL ADAPTATION}

\section{Jiang Haibin}

Summary: This article discusses current issues of planning future professional activities of modern students, the quality of which will depend not only on professional growth, but also on future productivity and quality of work.

Keywords: career, labor market, planning, graduate, employment, professionalism, adaptation.
$\mathrm{O}$ бщество, испытывая кризисные явления в социальной сфере, обуславливает важность выбора профессии. Технология планирования, условия, способствующие принятию правильного решения в вопросе выбора будущей профессии, являются одним из наиболее важных событий в жизни будущего профессионала. Выпускники вузов имеют низкую конкурентоспособность в условия современного спроса на рынке труда, обусловленную недостаточностью опыта, а также слабой способностью к профессиональной адаптации. Кроме того, процент трудоустроенных выпускников является отражением эффективности учебного заведения, поскольку показывает уровень ориентированности учебного заведения на реального работодателя. Целенаправленная стратегия будущей профессии, содействует повышению конкурентоспособности на рынке труда и успешности в трудовой деятельности.

Развитие российского общества, в последние годы, внесло существенные коррективы в характер определения, как моделей образования, так и трудовых ценностей, определяя во многом формирование уровней отношения к труду и влияя на мировоззрение современной молодежи. (Планирование профессиональной карьеры - это процесс, в котором студенты выбирают, проектируют, внедряют, модифицируют и совершенствуют свою будущую карьеру под руководством идеалов карьеры и теории планирования. [3, с.44]. Способность планирования профессиональной карьеры студентов является важным компонентом всестороннего качества и способностей студентов. [10, с.114]) Определение жизненных моделей, включает в себя, в том числе модели в сфере трудовой. Известный педагог, социолог Л.А. Гуцаленко, отмечал, что инновация деятельности базируется на «человеческом измерении» [1, с.54]. Действительно, поскольку новое создается людьми, то на них и лежит ответственность за внедрение в общество инноваций. Социальные изменения, конструируя новое, подвергаются не только воздействию глобальных факторов, но также испытывают давление со стороны индивидуальных субъективных микрофакторов. Особенно заметно влияние субъективных аспектов в жизненном пространстве современной молодёжи, что позволяет рассматривать жизнедеятельность молодых поколений в рамках субъектного феномена. Социальная субъектность молодёжи, находясь под влиянием преобладающих в обществе социальных доминант, определяется способностью субъекта к осуществлению самостоятельной социальной деятельности. Интеллектуальное развитие, способности к организации собственной жизни, возможность находить рациональный выход в разрешении жизненных противоречий, относятся к субъектным характеристикам. При этом способность соотнести самого себя с субъектом деятельности с одновременным интерпретированием уровня личной ответственности и себя, как причину личных жизненных перемен, по нашему мнению, стоит отнести к главным характеристикам феномена субъектности молодёжи [2, с.103]. Возможность рассмотрения духовного роста человека, с глубоким осмыслением содержания жизненного пути, позволяет рассматривать человека не только как источник предметно-практической формы познания, но и как фактор активности по отношению к объекту действия. Подобный подход достаточно освещён в трудах отечественных исследователей молодёжной социологии, таких как Ю.А. Зубок, В.И. Чупрова и позволяет перейти к рассмотрению субъектности молодёжи в контексте общественного воспроизводства [4, с.82]. 
Случаи профессиональной некомпетентности в условиях возрастающего спроса на профессионалов, в последние годы становятся частым явлением для России. Такая ситуация обуславливает всю систему образования выполнять работу по подготовке молодёжи, после окончании вуза, к эффективному вхождению в активную трудовую деятельность. Молодые специалисты, попадая в условия современного рынка труда, обнаруживают противоречия между полученными, за период обучения в вузе, профессиональными компетенциями и запросами рынка. Действительно, наряду с прилагаемыми значительными усилиями к организации теоретической подготовки, современные вузы, часто оказываются не вполне способными осуществить достижение необходимых практических навыков у своих студентов, что создаёт условия к снижению конкурентоспособности выпускников на рынке труда. Слабые практические профессиональные навыки, после окончания вуза, значительно увеличивают период поиска возможностей трудоустройства. Такая ситуация, закономерно, увеличивает время социальной адаптации и создаёт условия к появлению безработицы. Здесь стоит отметить серьёзный и деструктивный характер самого периода безработицы, поскольку факт отсутствия постоянного источника дохода, с течением времени оказывает не только разрушительное воздействие на психику молодого специалиста, но и способно привести к фрустрации личности, повышению уровня агрессии, потери смысловых жизненных конструкций [9, с.55]. Период безработицы, на фоне более успешных, работающих сверстников, негативно влияет на поиск возможностей социального роста. Кроме того, длительная трудовая неустроенность, понижает уровень профессионализма, повышая при этом страх перед самой возможностью трудоустроиться и способствуя развитию случаев девиантного поведения [5, с.162]. Подобная ситуация приводит к уникальному социальному феномену, когда молодые специалисты высокой квалификации оказываются профессионально непригодны к исполнению трудовых обязанностей на уровнях более низкой трудовой компетенции, как в производственном, так и в непроизводственном секторе отечественной экономики. Задержка более одного года периода безработицы, приводит к появлению феномена «волны», когда на рынок труда, после окончания вуза приходит новый поток выпускников, значительная часть которых не может получить работу, в соответствии с полученным образованием [7, с.37]. Так, по сведениям, предоставленным Федеральной службой государственной статистики, на основании выборочного обследования рабочей силы, в 2018 году, численность трудоустроенных выпускников вузов, за период с 2015 по 2017 год, составила 2447 тыс. человек. При этом, 713,5 тыс. выпускников были трудоустроены не по специальности, полученной в высшем учебном заведении, что в процентном соотношении составило 29\% [11]. Подобные исследования 2019 года, выявили уровень безработицы, среди выпускников отечественных вузов, на уровне 12,9\%. Обращение к исследованиям официальной статистики обнаруживает до 37\% выпускников управленческих и экономических профессий, работающих не по специальности. Одновременно с этим, выпускники медицинских профессий до 97\% сохранили приверженность выбранной профессии. Показатели «лидерства», среди выпускников вузов, в период с 2016 по 2018 год, неработающих по специальности, приобрели специальности, сельскохозяйственного направления $61 \%$, социальное направление профессий $53 \%$, экологическое и биотехнологическое направление 47\% [12]. Подобная статистика обуславливает значимость определения будущей профессии. По нашему мнению именно от выбора специальности будет определяться эффективность и качество социальной адаптации выпускников вузов страны. Известный российский социолог, один из основателей отечественного направления конфликтологических областей науки, М.А. Дмитриев формулирует основные направления профессиональной адаптации:

- психофизиологическое направление, включает в себя уровни адаптации субъекта, как существа биологического по отношению к физическим условиям трудовой среды;

- профессиональное направление интерпретирует профессиональный характер отношений субъекта к трудовым задачам и профессиональной информированности;

- социально-психологическое направление призвано отражать степень адаптации субъекта труда по отношению к социальным факторам трудовой среды [8, с.71].

Традиционно, основные критерии успешности трудовой адаптации выпускника вуза, находятся во взаимосвязанном отношении с оценочными категориями в системе: «профессиональная среда - человек». Тогда, по нашему мнению, уровень социальной адаптации, возможно, рассматривать в системе категорий: «результат трудовой деятельности - человек». Важным, в процессе подготовки будущего профессионала к самостоятельной трудовой деятельности, будет являться учебно-практическая среда, обеспечиваемая вузом [6, с.202]. Именно в вузе, по нашему мнению, должна быть создана адаптационная среда, способная сформировать осознанные убеждения у студентов, направленные на понимание правильности выбора будущей профессии. Подобная работа, может развиваться по следующим направлениям:

- эффективная профориентационная работа, проводимая со студентами старших курсов, направленная на формирование понимания о реальном состоянии рынка труда, в конкретном регионе;

- создание условий к максимальной практикоори- 
ентированной структуре учебных занятий (стажировка на предприятии, мастер-классы в реальных трудовых условиях и т.д.;

- необходимая корректировка учебных программ, в соответствии с требованиями рынка труда;

- работа над формированием личностных характе- ристик будущих профессионалов.

Подобная работа позволит успешно сформировать уровни профессиональной культуры у выпускников вузов, что в свою очередь, повысит возможность последующей социальной адаптации.

\section{ЛИТЕРАТУРА}

1. Боткова, В.К. Формирование карьерных стратегий молодежи в условиях студенческого самоуправления: социально-культурный подход / В.К. Боткова Москва, 2019. - 197 C.

2. Коргина, 0.А. Формирование стратегии профессионально-должностного продвижения управленческих кадров / 0.А. Коргина - Воронеж, 2019. - 209 с.

3. Лю Лихун. Укрепление руководства планированием профессиональной карьеры студентов, осуществление целенаправленного трудоустройства: 刘丽 红, 加强大学生职业生涯规划指导 实现精准就业: Китайское высшее образование / Лю Лихун - Пекин, 2018. - 64 с.

4. Маюров, В.Г. Экономическая теория [Текст] : монография / В. Г. Маюров. - Королев, 2015. - 307 с.

5. Настявин, И.М. Социология трудовой активности личности [Текст] : (опыт теоретико-прикладного исследования) : монография / И. М. Настявин - Казань : Изд-во КНИТУ, 2017. - 416 с.

6. Пахомова, Е.А. Становление территориальной многоуровневой системы педагогического сопровождения профессионального самоопределения обучающихся / Е.А. Пахомова - В. Новгород, 2017. - 479 с.

7. Рябкова, Л.А. Ценностные ориентации личности в процессе карьерного роста / Рябкова Людмила Анатольевна - Тюмень, 2019. - 207 с.

8. Толочек, В.А. Профессиональная карьера как социально-психологический феномен [Текст] / В. А. Толочек ; Российская академия наук, Институт психологии. - Москва : Ин-т психологии РАН, 2017. - 261 с.

9. Шамсутдинова, А.В. Социальная адаптация студентов в процессе планирования профессиональной карьеры / А.В. Шамсутдинова - Киров, 2015. - 190 с.

10. Чжао Цзичэн, Цао Ин. Существующие проблемы и контрмеры в процессе руководства планированием профессиональной карьеры студентов: 赵梓 丞, 曹迎. 大学生职业生涯规划指导存在的问题与对策: / Чжао Цзичэн, Цао Ин; Исследование высшего инженерного образования Ухань, 2019. - 200 c.

11. Федеральная служба статистики PФ URL: https://www.gks.ru/labour_force (Дата обращения14.06.2020).

12. Федеральная служба статистики PФ URL: https://gks.ru/compendium/document/13265 (Дата обращения14.06.2020).

(с) Цзян Хайбинь (37694350@qq.com). 